\title{
Incidence of clinical mastitis and distribution of pathogens on large Chinese dairy farms
}

\author{
Jian Gao, ${ }^{*}$ Herman W. Barkema,† Limei Zhang, ${ }^{*}$ Gang Liu, ${ }^{*}$ Zhaoju Deng,‡ Lingjie Cai,§ Ruixue Shan, ${ }^{*}$ \\ Shiyao Zhang, ${ }^{*}$ Jiaqi Zou, ${ }^{*}$ John P. Kastelic,† and Bo Han*1 \\ *Department of Clinical Veterinary Medicine, College of Veterinary Medicine, China Agricultural University, Beijing 100193, P.R. China \\ †Department of Production Animal Health, Faculty of Veterinary Medicine, University of Calgary, Calgary, AB, Canada, T2N 4N1 \\ ‡Department of Farm Animal Health, Faculty of Veterinary Medicine, Utrecht University, Yalelaan 7, $3584 \mathrm{CL}$, Utrecht, the Netherlands \\ §Animal Health Cattle, Boehringer Ingelheim International Trading (Shanghai) Co. Ltd., 18/F Building A, Pingan International Financial Center 3 , \\ South Xinyuan Road, Beijing, 100027, China
}

\section{ABSTRACT}

Knowledge of the incidence of clinical mastitis (CM) and the distribution of pathogens involved is essential for development of prevention and control programs as well as treatment protocols. No country-wide study on the incidence of $\mathrm{CM}$ and the distribution of pathogens involved has been conducted in China. Core objectives of this study were, therefore, to determine the cumulative incidence of $\mathrm{CM}$ and the distribution of pathogens causing $\mathrm{CM}$ on large Chinese (>500 cows) dairy farms. In addition, associations between the distribution of CM pathogens and bedding materials and seasonal factors were also investigated. Bacterial culture was done on a total of 3,288 CM quarter milk samples from 161 dairy herds (located in 21 provinces) between March 2014 and September 2016. Additional data, including geographical region of herds, herd size, bedding types, and number of $\mathrm{CM}$ cases during the last month, were also recorded. Mean cumulative incidence of $\mathrm{CM}$ was 3.3 cases per 100 cows per month (range $=1.7$ to 8.1). The most frequently isolated pathogens were Escherichia coli (14.4\%), Klebsiella spp. (13.0\%), coagulasenegative staphylococci (11.3\%), Streptococcus dysgalactiae (10.5\%), and Staphylococcus aureus (10.2\%). Streptococcus agalactiae was isolated from $2.8 \%$ of CM samples, whereas Streptococcus uberis were isolated from $2.1 \%$ of samples, and $15.8 \%$ of 3,288 samples were culture-negative. Coagulase-negative staphylococci, E. coli, and other Enterobacter spp. were more frequently isolated in the northwest than the northeast or south of China. Streptococcus dysgalactiae, other streptococci, and Strep. agalactiae were more frequently isolated in winter (October-March), whereas E. coli and Klebsiella

\footnotetext{
Received November 19, 2016.

Accepted March 2, 2017.

${ }^{1}$ Corresponding author: hanbo@cau.edu.cn
}

spp. were mostly isolated in summer (April-September). Streptococcus dysgalactiae was more often isolated from CM cases of herds using sand bedding, whereas Klebsiella spp. and other streptococci were more common in herds using organic bedding. The incidence of $\mathrm{CM}$ and distribution of pathogens differed among herds and better mastitis management is needed. Furthermore, geography, bedding materials, and season should be included when designing mastitis control and prevention schemes for Chinese dairies.

Key words: clinical mastitis, pathogen, distribution, season, bedding material

\section{INTRODUCTION}

Bovine mastitis is a common and costly disease for the dairy industry worldwide (Bradley, 2002), resulting in much involuntary culling. Identification of pathogens causing clinical mastitis (CM) enables appropriate choices for antibiotic treatment (Pinzón-Sánchez et al., 2011) and preventive mastitis management. The distribution of pathogens isolated from CM samples differs considerably among countries and regions (Erskine et al., 1988; Barkema et al., 1998; McDougall, 1999; Bradley et al., 2007; Olde Riekerink et al., 2008; Ericsson-Unnerstad et al., 2009; Oliveira et al., 2013; Verbeke et al., 2014). For example, in Norway and Sweden, Staphylococcus aureus is the most frequently isolated pathogen from CM samples, followed by Streptococcus dysgalactiae and Escherichia coli, respectively (Reksen et al., 2006; Ericsson-Unnerstad et al., 2009). In the Netherlands, Klebsiella mastitis occurs less frequently than CM caused by E. coli (Barkema et al., 1998), whereas in the United States, Klebsiella and E. coli mastitis are of equal importance (Barkema et al., 1998; Roberson et al., 2004). In New Zealand, coliforms are less prevalent as CM pathogens, but Streptococcus uberis is the main pathogen causing both clinical and subclinical mastitis (McDougall, 1999). 
Type of bedding and daily bedding management can have a major effect on udder health and the incidence of IMI and mastitis (Hogan et al., 1989). Organic materials are often used as bedding, but they support rapid growth of environmental mastitis pathogens, especially when mixed with manure and urine (Hogan et al., 1990; Ericsson-Unnerstad et al., 2009). Sand, an inorganic bedding material that does not support the growth of bacteria, is considered to be the gold standard bedding material (Stowell and Inglis, 2000). Fewer coliform bacteria and environmental streptococci are present in clean sand than in organic bedding (Stowell and Inglis, 2000). Exposure to lower bacteria counts is associated with reduced rates of mastitis with environmental pathogens (Hogan et al., 1989, 1999).

Climatologic factors affect the incidence of CM (Morse et al., 1988). Seasonal effects are also an issue for pathogen-specific CM, with a higher incidence of streptococcal and coliform CM in the summer (Hogan et al., 1989; Makovec and Ruegg, 2003; Olde Riekerink et al., 2008). Higher humidity and temperature in summer increase bacterial counts in bedding material, resulting in an increased incidence rate of CM caused by these pathogens (Smith et al., 1985; Erskine et al., 1988).

In China, the number of large dairy farms is increasing. As management systems differ among regions, regular national-scale studies on the incidence of CM are indispensable to devise appropriate mastitisprevention programs. The distribution of pathogens causing subclinical mastitis in Chinese dairy cows was recently reported (Bi et al., 2016), with Strep. agalactiae the most frequently isolated pathogen. However, in contrast to subclinical mastitis, a lack of national information exists on pathogens associated with CM in large Chinese dairy farms. The primary objective of our study was therefore to determine the cumulative incidence of CM (CICM) and distribution of pathogens that cause CM on large Chinese dairy farms. Another objective was to determine associations between distribution of pathogen-specific CM and bedding material and seasonal factors.

\section{MATERIALS AND METHODS}

\section{Herds}

Herds included in the study voluntarily participated in a large dairy farm mastitis program of the Animal Health Department of Boehringer Ingelheim (BI) in China. Herds involved had a minimum of 500 lactating Holstein-Friesian cows that were fed a TMR, milked in a milking parlor, and housed in freestalls. Herds were added and some stopped participating during the 2.5-yr study period. Herds were located in 3 major geographic regions of China (south, northeast, and northwest; Figure 1).

\section{Samples}

Herd veterinarians were asked to collect a milk sample aseptically from quarters that had visible signs of CM before antibiotic treatment was initiated. Cases of CM were detected routinely by herd supervisors at milking time and confirmed by a veterinarian. Veterinarians collected milk samples from every quarter that had visible signs of clinical mastitis, abnormal milk, or swollen quarter(s) before treatment. Aseptic sampling procedures were discussed before the start of the project. No fixed number of CM samples to be submitted was used, and, in general, larger herds were encouraged to submit more samples. Herds often submitted several batches of samples. However, only the first submitted batch of CM samples was included in the current study. Sampling instructions were provided by the Mastitis Diagnostic Laboratory of China Agriculture University (MDLCAU; Beijing, P.R. China). Producers received a milk sampling package consisting of sample tubes, recording forms, labels, and a protocol for aseptic collection of milk samples. Milk samples were commonly stored in a freezer on the farm (at approximately $-20^{\circ} \mathrm{C}$ ), then placed on an ice pack and sent (express mail) to MDLCAU for bacterial culture. Herds were advised not to store the samples for a prolonged interval (in general not $>3 \mathrm{~d}$ ). Basic farm information, including sampling date, herd size, bedding material and number of cases of $\mathrm{CM}$ in the last month (30 d before sampling time) extracted from the farm records, were also recorded, although parity, DIM, quarter location, severity of clinical signs and treatment procedures were not requested.

\section{Microbiological Culture}

Upon arrival at MDL-CAU, all frozen samples were thawed at room temperature. Microbiologic procedures were conducted according to guidelines of NMC (1999). In short, $10 \mu \mathrm{L}$ of milk from each sample was plated onto a blood agar and a MacConkey agar plate (Luqiao, Beijing, China), and plates were incubated at $37^{\circ} \mathrm{C}$ for 24 to $48 \mathrm{~h}$. Samples were considered culture-positive if 1 or more colonies were observed ( $\geq 100 \mathrm{cfu} / \mathrm{mL}$; Verbeke et al., 2014). Milk samples with 3 or more species were considered contaminated, unless Staph. aureus or Strep. agalactiae were isolated. Staphylococcus aureus was identified by $\alpha$ - and $\beta$-hemolysis on blood agar, Gram staining, a positive catalase test, a positive tube 
coagulase test, mannitol reaction, and presence of nuc gene (Gao et al., 2011). Suspected Streptococcus spp. were identified as catalase-negative and gram-positive cocci. Streptococci were differentiated as esculin-positive (Strep. uberis and other esculin-positive cocci) or esculin-negative cocci (Strep. dysgalactiae and Strep. agalactiae). Christie, Atkins, and Munch-Petersen (CAMP) tests (Tianhe, Hangzhou, China) were used to distinguish Strep. dysgalactiae (CAMP-negative) from Strep. agalactiae (CAMP-positive). Streptococci not identified by the above procedures were confirmed by $16 \mathrm{~S}$ rDNA sequencing (Frank et al., 2008). Gram- negative bacteria were identified using MacConkey agar, Gram staining, motility, indole, ornithine reactions, oxidase, and growth on triple sugar iron slants. The API 20 E system (bioMérieux SA, Marcy-l'Étoile, France) was used to identify gram-negative bacteria that could not be identified by the above procedures. Prototheca and yeasts were identified by visual assessment of colony morphology and microscopic examination at $400 \times$ magnification. Species that could not be classified using previously mentioned test procedures were subjected to $16 \mathrm{~S}$ rDNA sequencing (Frank et al., 2008).

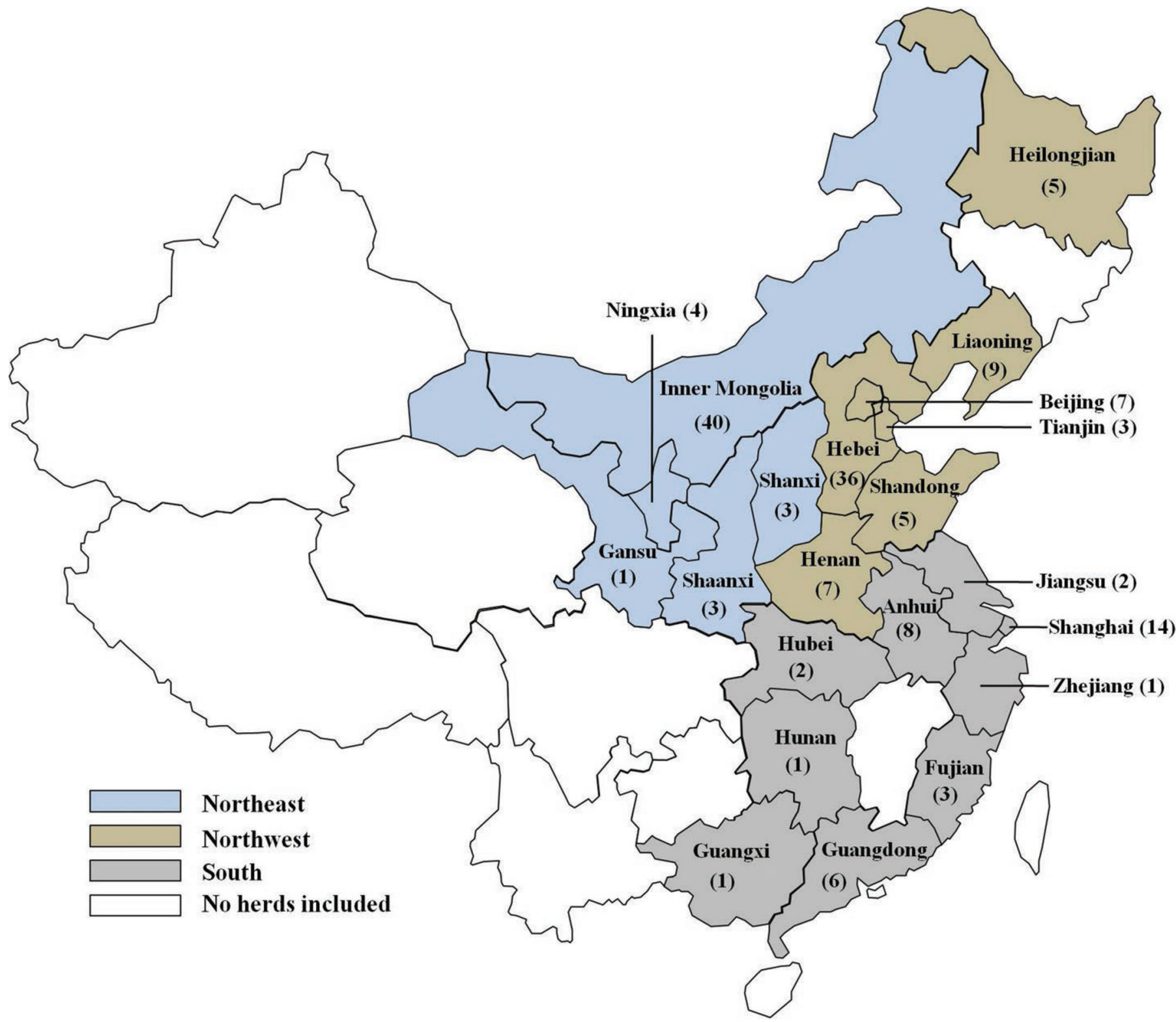

Figure 1. Geographic distribution of the 161 dairy herds and number of herds in each province of China. Color version available online. 


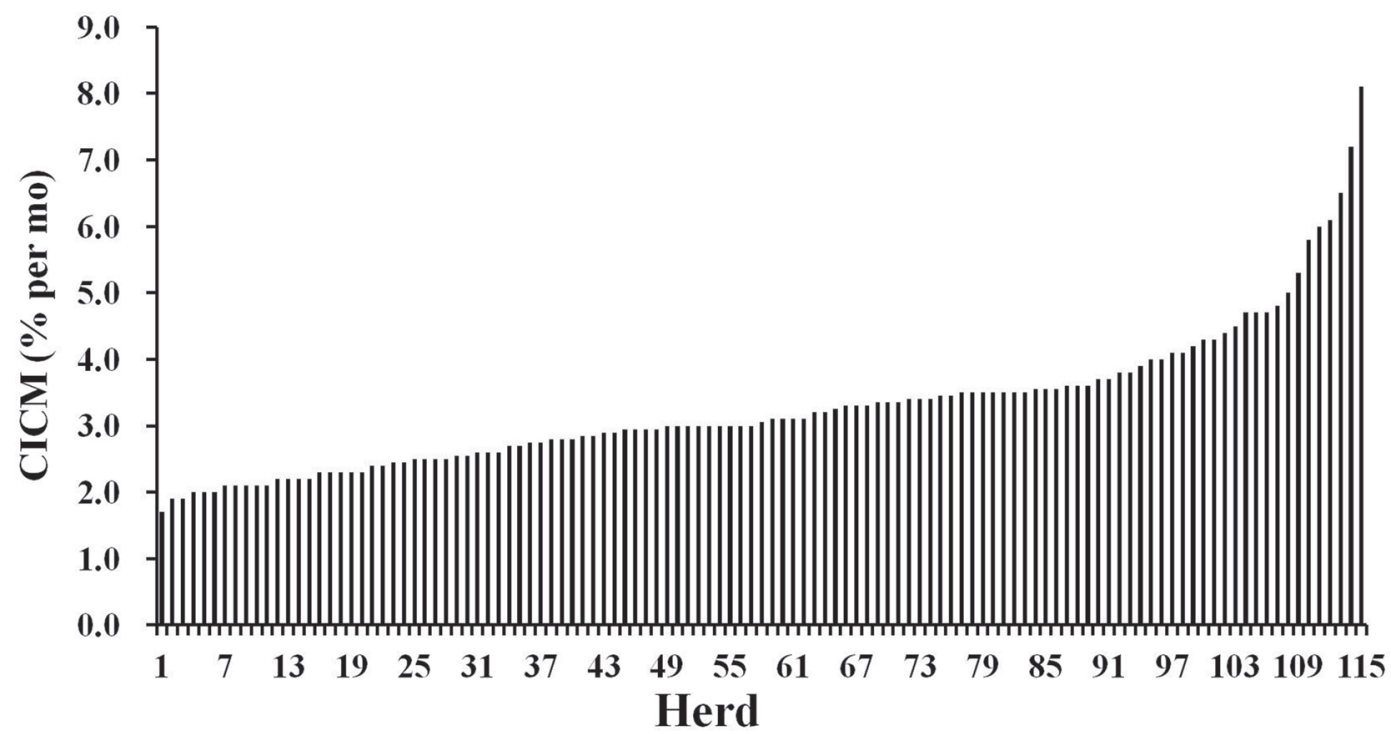

Figure 2. Cumulative incidence of clinical mastitis (CICM) in 115 of 161 Chinese dairy herds that submitted milk samples.

\section{Statistical Analyses}

All statistical analyses were done with SPSS v20.0 (SPSS Inc., Chicago, IL). A $P$-value $<0.05$ was considered significant. Means and standard deviations were calculated. One-way ANOVA and 2-tailed Student's ttests were used to compare distributions of CM pathogens with regards to region, season, bedding type, and CICM between the 2 seasons. Regions were defined as northeast, northwest, and south China (Figure 1). The CICM was calculated as the number of cows with $\mathrm{CM}$ per 100 cows present per month in a herd.

\section{RESULTS}

\section{Herd Characteristics}

A total of 3,288 quarter milk samples collected from 3,190 dairy cows in 161 herds were submitted to the MDL-CAU for bacterial culture between March 2014 and September 2016. Herds were located in 21 Chinese provinces (Figure 1), which contained $>90 \%$ of Chinese dairy farms. There were 72 farms in 7 provinces of northeast China, 51 farms were in 5 provinces of northwest China, and 38 farms in 9 provinces of southern China (Figure 1). Inner Mongolia (25\% of herds) and Hebei (22\% of herds) had the largest proportion of participating herds (40 and 36, respectively). Average and median herd size were 1,912 and 1,150 lactating cows (range, 511 to 9,032 cows). A total of 72 (45\%) dairy farms used organic materials for bedding, whereas the other 89 (55\%) farms used sand. Organic bedding included recycled manure, saw dust, rice hull (or a mixture of those materials), whereas inorganic bedding was exclusively sand. All participating herds used new sand. Sand bedding was cleaned 3 times per day (during milking) to remove all organic materials. In general, fresh new sand was added to the bedding once per week, according to the bedding thickness.

\section{Incidence of Clinical Mastitis}

A total of 115 (71\%) of 161 farms supplied number of cases of $\mathrm{CM}$ in the $30 \mathrm{~d}$ before sampling (Figure 2). Mean herd CICM was 3.3\% per month in the herds and median CICM was $3.0 \%$ per month (range $=1.7$ to 8.1 per herd).

\section{Culture Results}

Among all enrolled cows, 98 (3.1\%) of 3,190 cows had 2 quarters affected with $\mathrm{CM}$ at sampling. In total, 2,767 CM samples (84.2\%) were culture positive, whereas $521(15.8 \%)$ of CM samples yielded no growth. Of 3,288 samples, $3.8 \%$ were defined as contaminated. Among culture-positive samples, E. coli was most frequently isolated $(14.4 \%)$, followed by Klebsiella spp. (13.0\%), CNS (11.3\%), Strep. dysgalactiae (10.5\%), Staph. aureus (10.2\%), and other streptococci (8.0\%). Enterobacter spp., Strep. agalactiae, and Strep. uberis were isolated in 5.5, 2.8, and $2.1 \%$ of samples, respectively (Table 1). Mixed cultures were isolated in 120 $(3.6 \%)$ CM samples. Yeasts were the most frequently isolated nonbacterial pathogens $(1.0 \%)$, whereas other pathogens were isolated in $5.1 \%$ of samples. 
Table 1. Distribution of pathogens isolated from 3,288 clinical mastitis samples from 161 large (>500 cows) Chinese dairy herds

\begin{tabular}{lrrrrr}
\hline & \multicolumn{2}{c}{ Samples } & & \multicolumn{2}{c}{ Herds $^{1}$} \\
\cline { 2 - 3 } \cline { 5 - 6 } Pathogen & \multirow{2}{*}{ No. } & $\%$ & & No. & $\%$ \\
\hline Escherichia coli & 473 & 14.4 & & 120 & 74.5 \\
Klebsiella spp. & 426 & 13.0 & & 98 & 60.9 \\
CNS & 372 & 11.3 & & 102 & 63.4 \\
Streptococcus dysgalactiae & 346 & 10.5 & & 95 & 59.0 \\
Staphylococus aureus & 337 & 10.2 & & 90 & 55.9 \\
Other streptococci & 264 & 8.0 & & 85 & 52.8 \\
Enterobacter spp. & 182 & 5.5 & & 74 & 46.0 \\
Streptococcus agalactiae & 92 & 2.8 & & 25 & 15.5 \\
Streptococcus uberis & 70 & 2.1 & & 23 & 14.3 \\
Pseudomonas spp. & 45 & 1.4 & & 25 & 15.5 \\
Bacillus hemolysis & 41 & 1.2 & & 18 & 11.2 \\
Yeast & 32 & 1.0 & & 15 & 9.3 \\
Trueperella pyogenes & 30 & 0.9 & & 16 & 9.9 \\
Aerococcus viridans & 21 & 0.6 & & 16 & 9.9 \\
Corynebacterium bovis & 20 & 0.6 & & 20 & 12.4 \\
Pasteurella spp. & 5 & 0.2 & & 4 & 2.5 \\
Others & 6 & 0.2 & & 5 & 3.1 \\
Mixed culture & 120 & 3.6 & & 61 & 37.9 \\
Culture negative & 521 & 15.8 & & 120 & 74.5 \\
Contamination & 125 & 3.8 & & 64 & 39.8 \\
\hline
\end{tabular}

${ }^{1}$ Number and percentage of herds with at least one sample positive for a pathogen.

\section{Region}

Across China, 1,063 CM samples were collected from southern China, whereas 1,271 and 954 samples were obtained from the northeast and northwest, respectively. Mean monthly CICM was 3.1, 2.7, and $4.3 \%$ per month for herds in the northeast, northwest, and south, respectively. Distribution of major CM pathogens differed by region (Table 2). Percentage of CNS (6.7\%) was lower, but E. coli $(20.5 \%)$ and other Enterobacter spp. (8.3\%) were higher in northwest herds than in northeast and southern herds. Proportion of culture- negative samples $(20.6 \%)$ was higher in herds from southern China. Isolation rates of Strep. dysgalactiae differed among the 3 regions.

\section{Sampling Season}

A total of 1,287 CM samples were collected in winter (October-March), whereas 2,001 samples were obtained in summer (April-September; Table 3). In winter (October-March) mean monthly CICM was $3.0 \%$ per month, whereas in summer CICM was $3.4 \%$ per month (Figure 3; $P<0.05$ ). Distribution of major pathogens differed by sampling season (Table 3). Streptococcus dysgalactiae, other streptococci, and Strep. agalactiae were more frequently isolated in winter, whereas $E$. coli and Klebsiella spp. were more prevalent in summer.

\section{Bedding Material}

Of 3,288 CM samples, 1,750 were collected from herds using sand bedding, whereas 1,538 samples were from herds using organic bedding materials (Table 4). None of the 161 herds used straw as a bedding material. Mean monthly CICM was 2.9 and $3.7 \%$ for herds using sand and organic bedding material, respectively. Streptococcus dysgalactiae was more frequently isolated in herds using sand bedding than those using organic bedding, whereas Klebsiella spp. and other streptococci were more prevalent in herds using organic bedding.

\section{DISCUSSION}

In the current study on a considerable number of large Chinese dairy herds, average CICM was $3.3 \%$ per month, and E. coli, Klebsiella spp., CNS, Strep. dysgalactiae, and Staph. aureus were the most com-

Table 2. Distribution of selected pathogens isolated from clinical mastitis samples in 3 regions of China from 3,288 milk samples collected from 161 large (>500 cows) dairy herds

\begin{tabular}{|c|c|c|c|c|c|c|}
\hline \multirow[b]{3}{*}{ Pathogen } & \multicolumn{6}{|c|}{ Region } \\
\hline & \multicolumn{2}{|c|}{$\begin{array}{l}\text { Northeast } \\
(\mathrm{n}=1,271)\end{array}$} & \multicolumn{2}{|c|}{$\begin{array}{l}\text { Northwest } \\
(\mathrm{n}=954)\end{array}$} & \multicolumn{2}{|c|}{$\begin{array}{c}\text { South } \\
(\mathrm{n}=1,063)\end{array}$} \\
\hline & No. & $\%$ & No. & $\%$ & No. & $\%$ \\
\hline Staphylococcus aureus & 179 & 13.1 & 85 & 8.8 & 73 & 7.3 \\
\hline CNS & 146 & $12.4^{\mathrm{a}}$ & 58 & $6.7^{\mathrm{ab}}$ & 168 & $14.5^{\mathrm{b}}$ \\
\hline Streptococcus dysgalactiae & 143 & $10.0^{\mathrm{a}}$ & 138 & $14.8^{\mathrm{a}}$ & 65 & $6.0^{\mathrm{a}}$ \\
\hline Other streptococci & 109 & 8.5 & 57 & 6.6 & 98 & 10.6 \\
\hline Streptococcus agalactiae & 46 & 4.8 & 23 & 2.2 & 23 & 2.8 \\
\hline Escherichia coli & 171 & $14.5^{\mathrm{a}}$ & 175 & $20.5^{\mathrm{ab}}$ & 127 & $12.3^{\mathrm{b}}$ \\
\hline Klebsiella spp. & 183 & 14.4 & 120 & 10.5 & 123 & 12.1 \\
\hline Enterobacter spp. & 51 & $4.7^{\mathrm{a}}$ & 73 & $8.3^{\mathrm{ab}}$ & 58 & $4.5^{\mathrm{b}}$ \\
\hline Culture negative & 146 & $10.0^{\mathrm{a}}$ & 148 & $14.1^{\mathrm{b}}$ & 227 & $20.6^{\mathrm{ab}}$ \\
\hline
\end{tabular}

${ }^{\mathrm{a}, \mathrm{b}}$ Within a row, percentage of pathogens without a common superscript differed $(P<0.05)$. 
Table 3. Distribution of major mastitis pathogens in winter and summer from 3,288 clinical mastitis milk samples in 161 large (>500 cows) Chinese dairy herds

\begin{tabular}{|c|c|c|c|c|}
\hline \multirow[b]{3}{*}{ Pathogen } & \multicolumn{4}{|c|}{ Sampling season ${ }^{1}$} \\
\hline & \multicolumn{2}{|c|}{$\begin{array}{c}\text { Winter } \\
(\mathrm{n}=1,287)\end{array}$} & \multicolumn{2}{|c|}{$\begin{array}{c}\text { Summer } \\
(\mathrm{n}=2,001)\end{array}$} \\
\hline & No. & $\%$ & No. & $\%$ \\
\hline Staphylococcus aureus & 144 & 11.3 & 193 & 9.8 \\
\hline CNS & 120 & 9.2 & 252 & 12.1 \\
\hline Streptococcus dysgalactiae & 203 & $16.3^{\mathrm{a}}$ & 143 & $7.5^{\mathrm{a}}$ \\
\hline Other streptococci & 122 & $11.1^{\mathrm{a}}$ & 142 & $6.9^{\mathrm{a}}$ \\
\hline Streptococcus agalactiae & 63 & $6.3^{\mathrm{a}}$ & 29 & $2.0^{\mathrm{a}}$ \\
\hline Escherichia coli & 138 & $10.6^{\mathrm{a}}$ & 335 & $18.8^{\mathrm{a}}$ \\
\hline Klebsiella spp. & 112 & $8.3^{\mathrm{a}}$ & 314 & $15.0^{\mathrm{a}}$ \\
\hline Enterobacter spp. & 75 & 5.5 & 107 & 5.9 \\
\hline Culture negative & 205 & 13.6 & 316 & 13.9 \\
\hline
\end{tabular}

${ }^{a}$ Within a row, percentage of pathogens without a common superscript differed $(P<0.05)$.

${ }^{1}$ Winter $=$ October-March; Summer $=$ April-September

monly isolated bacteria. To our knowledge, this was the first China-wide study on incidence rate of $\mathrm{CM}$ and associated pathogens. In recent years, the Chinese dairy industry has experienced substantial structural changes, with a rapid increase in number of large herds. It was noteworthy that many large-scale farms were included in our study. The new knowledge generated in our study should be indispensable for preventing and treating $\mathrm{CM}$ cases, including development of regional and national mastitis prevention and control programs.
The average CICM in our study of $3.3 \%$ per month equates to approximately 37 cases per year; this incidence falls in the range of previous reports (Daniel et al., 1982; Wilesmith et al., 1986; Erskine et al., 1988; Schukken et al., 1989a; Barkema et al., 1998; Bradley et al., 2007; Olde Riekerink et al., 2008). Because this was apparently the first nationwide study in China, no other Chinese studies are available for comparison.

In our study, most $(45 \%)$ cases of CM were caused by gram-positive cocci, followed by gram-negative

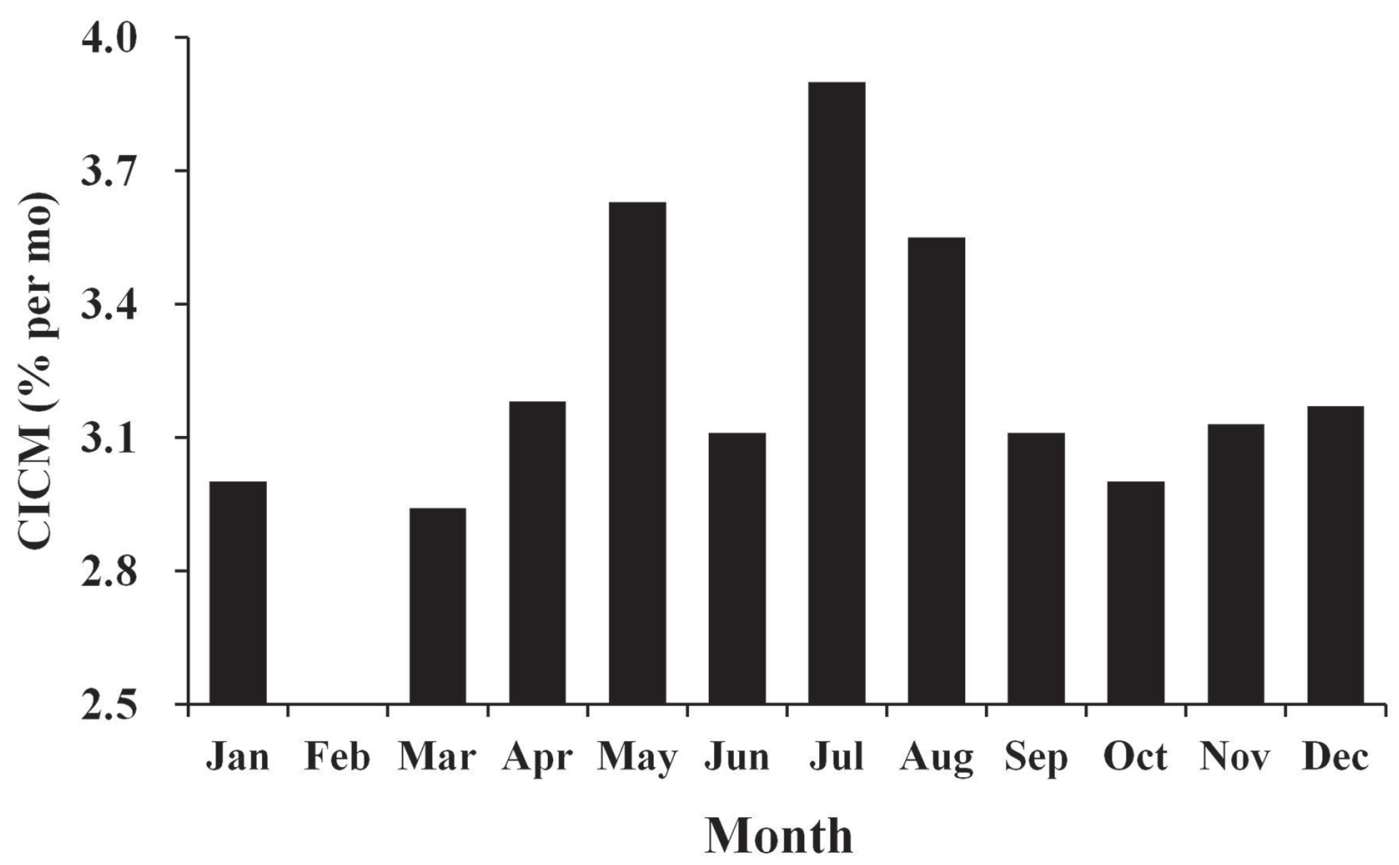

Figure 3. Distribution of cumulative incidence of clinical mastitis (CICM) in 115 large Chinese dairy herds over the year. No samples were submitted in February due to the Spring Festival. 
Table 4. Distribution of major clinical mastitis pathogens from 3,288 milk samples in 161 large Chinese dairy herds using 2 kinds of bedding material

\begin{tabular}{|c|c|c|c|c|}
\hline \multirow[b]{3}{*}{ Pathogen } & \multicolumn{4}{|c|}{ Bedding material } \\
\hline & \multicolumn{2}{|c|}{$\begin{array}{c}\text { Sand } \\
(\mathrm{n}=1,750)\end{array}$} & \multicolumn{2}{|c|}{$\begin{array}{c}\text { Organic } \\
(\mathrm{n}=1,538)\end{array}$} \\
\hline & No. & $\%$ & No. & $\%$ \\
\hline Staphylococcus aureus & 196 & 11.3 & 141 & 9.2 \\
\hline CNS & 189 & 10.8 & 183 & 11.5 \\
\hline Streptococcus dysgalactiae & 225 & $13.4^{\mathrm{a}}$ & 121 & $7.0^{\mathrm{a}}$ \\
\hline Other streptococci & 112 & $6.6^{\mathrm{a}}$ & 152 & $10.6^{\mathrm{a}}$ \\
\hline Streptococcus agalactiae & 73 & 4.6 & 19 & 2.2 \\
\hline Escherichia coli & 264 & 16.9 & 209 & 14.7 \\
\hline Klebsiella spp. & 177 & $10.2^{\mathrm{a}}$ & 249 & $15.7^{\mathrm{a}}$ \\
\hline Enterobacter spp. & 101 & 6.3 & 81 & 5.1 \\
\hline Culture negative & 273 & 12.8 & 248 & 14.9 \\
\hline
\end{tabular}

${ }^{a}$ Percentage of pathogens on the same row having a common superscript differed $(P<0.05)$.

pathogens (33\%), which was the opposite of a study that included milk samples from CM cases in large US dairy farms (Oliveira et al., 2013). Environmental pathogens appeared to be the most frequent cause of $\mathrm{CM}$ in Chinese farms, similar to other regions in the world (Bradley et al., 2007; Olde Riekerink et al., 2008; Oliveira et al., 2013; Verbeke et al., 2014). However, Staph. aureus was isolated from $10 \%$ of samples collected from $56 \%$ of studied herds, similar to results of CM studies conducted in Canada (Olde Riekerink et al., 2008; Levison et al., 2016), lower than reported in a Swedish study (Ericsson-Unnerstad et al., 2009), but higher than other CM studies (McDougall, 1999; Bradley et al., 2007; Oliveira et al., 2013). A high prevalence of Staph. aureus and Strep. agalactiae was recently reported in bulk milk samples (Bi et al., 2016), as well as Strep. agalactiae, Staph. aureus, and Strep. dysgalactiae in IMI from Chinese herds (Zhang et al., 2016); therefore, these 3 bacterial species were considered the predominant pathogens associated with subclinical mastitis. Based on high isolation rates of Staph. aureus, Strep. dysgalactiae, and Strep. agalactiae from both subclinical and clinical mastitis samples (an isolation rate in CM samples of $2.8 \%$ is relatively high for Strep. agalactiae, a predominantly subclinical pathogen), we inferred that better contagious mastitiscontrol programs should be implemented in Chinese herds. Several studies reported that Strep. uberis was the most prevalent streptococcal species isolated from CM (McDougall, 1999; Roberson et al., 2004; Bradley et al., 2007; Olde Riekerink et al., 2008; Verbeke et al., 2014). The low proportion of Strep. uberis in these large Chinese dairy herds was attributed to the cows being confined and not managed on pasture. Additionally, straw, which is associated with Strep. uberis CM (e.g., Ericsson Unnerstad et al., 2009), is in contrast to sawdust rarely used as a bedding material on Chinese dairy farms.

It was notable that Klebsiella spp. were isolated from $61 \%$ of studied herds and was the second most frequently isolated pathogen in the present CM study. Klebsiella infections are typically very difficult to treat, and infected animals or individual quarters usually have to be culled (Podder et al., 2014). In addition, economic losses due to Klebsiella spp. are much greater compared with losses caused by E. coli due to reduced cow survival and decreased milk production (Gröhn et al., 2004, 2005). Given the lower proportion of Klebsiella-positive CM samples in herds using sand bedding and the lower CICM in these herds, herds with a high Klebsiella CICM that use organic bedding should be advised to change bedding to sand (if possible). Growth of bacteria is low in sand bedding because of the low organic content (e.g., Kristula et al., 2005). It is therefore important when using sand bedding to keep it clean so that the organic content is maintained as low as possible.

As the contamination rate of samples herein seemed lower than other reports (Olde Riekerink et al., 2008; Verbeke et al., 2014), we inferred that milk samples were collected in accordance with the supplied sampling procedure. The percentage of negative samples in our study seemed slightly lower than results from other studies (Olde Riekerink et al., 2008; Oliveira et al., 2013; Verbeke et al., 2014). Perhaps this was due to storage of some samples at $4^{\circ} \mathrm{C}$ instead of freezing, as freezing and thawing of samples decreased culture sensitivity of E. coli (Schukken et al., 1989b). Culture methods used in our study were not designed to detect Mycoplasma spp., as this pathogen requires special media and culture conditions. Therefore, no conclusions can be drawn on the CICM of Mycoplasma spp., 
a pathogen that has been detected on large dairy farms in China (Qi et al., 2012).

Although the climate in northwest of China is mostly cool and dry, a high proportion of environmental pathogens, including E. coli and other Enterobacter spp., were detected. In the absence of management details of studied herds (e.g., dry cow and calving management, lactation number and lactating days of infected cows, maintenance of bedding and cleanness of cows), we were unable to interpret these findings. The higher percentage of culture-negative samples in southern herds may have been caused by death of pathogens during prolonged transportation from farms to MDLCAU (located in the north of China).

Seasonal effects on pathogen-specific CM have been reported. In Norway, Staph. aureus, E. coli, and Strep. dysgalactiae were most prevalent in winter, whereas incidence of CM caused by Strep. uberis was higher in August (Osterås et al., 2006). China is located in the northern hemisphere; thus, it is cold and dry in winter, but hot and wet in the summer. In our study, CICM of streptococci, including Strep. dysgalactiae, environmental streptococci, and Strep. agalactiae, was higher in the winter than the summer. High prevalence of Strep. dysgalactiae in winter was similar to Norwegian and Canadian studies (Osterås et al., 2006; Olde Riekerink et al., 2007), but not in agreement with another study (Makovec and Ruegg, 2003). In the summer, coliforms, including E. coli and Klebsiella spp., were more frequently isolated from $\mathrm{CM}$, which was not consistent with a previous study in Canada (Olde Riekerink et al., 2007) but was similar to a series of US studies (Hogan et al., 1989; Todhunter et al., 1991; Makovec and Ruegg, 2003). In the present study, all herds were confined, which was similar to herds in those US studies. It has been demonstrated that, compared with pastured herds, confined herds had a higher incidence of coliform CM in the summer (Olde Riekerink et al., 2007), whereas incidence of $E$. coli $\mathrm{CM}$ was lower in summer in herds that kept cows on pasture day and night (Barkema et al., 1999). In summer, heat and humidity enhance the growth of $E$. coli in the environment, resulting in high coliform counts in bedding (Smith et al., 1985; Hogan et al., 1989) and therefore greater exposure to the pathogen.

Bedding types were roughly divided into sand and organic materials, as most farms using organic materials had some mixture of materials (but detailed composition was not supplied by farm producers). In a previous study, lactating cows on farms with organic materials used for bedding had higher coliforms, Klebsiella species, and streptococcal counts than those bedded on inorganic materials (Hogan et al., 1989). In a Swed- ish study, Klebsiella $\mathrm{CM}$ was associated with sawdust bedding, whereas Strep. uberis CM was associated with straw or peat as a bedding material (Ericsson Unnerstad et al., 2009). In the present study, Klebsiella spp. and environmental streptococci were more frequently isolated from herds using organic materials, whereas E. coli was not. Environmental pathogens usually do not colonize teat skin for prolonged intervals. Bacterial counts on teat ends are correlated with bacterial counts in organic bedding (Hogan et al., 1989, 1999; Zdanowicz et al., 2004). Counts of both E. coli and Klebsiella spp. were higher on teat ends of cows housed on sawdust compared with sand (Zdanowicz et al., 2004). It was recently reported that fewer cases of CM were caused by gram-negative bacteria for primiparous cows housed in pens containing new sand than in other bedding types (Rowbotham and Ruegg, 2016). Thus, we speculate many organic products contained high levels of a resident population of potential pathogens before they were used as bedding. A source of other streptococci was dried manure (in farms using recycled dry manure), whereas Klebsiella spp. mainly came from fresh sawdust (Hogan et al., 1999). Physical properties of sand (e.g., poor adhesion to skin) may lead to bacterial exposure in a more sporadic manner than is the case for sawdust (Zdanowicz et al., 2004).

Studies such as ours that rely on herd personnel and herd veterinarians to collect and submit samples of $\mathrm{CM}$ cases have drawbacks. Not all cases of CM were sampled and it is not known how cases of $\mathrm{CM}$ that were submitted for culture were selected. It is possible that particularly severe cases of CM were selected and that repeat cases were only sampled if no sample was submitted the first time the cow had CM. Also, it is likely that cows on not-to-breed or cull lists were not sampled. It was not possible to estimate the level of bias that may have been introduced, and this may have affected pathogen distribution. For example, if particularly more severe cases of CM were submitted and less so repeated cases, gram-negative pathogens that, on average, cause more severe CM and less repeated CM cases such as E. coli would have been overrepresented (Barkema et al., 1998; Verbeke et al., 2014).

The herds voluntarily participated in the current project, and, except for the size of the lactating herd (>500 cows), they were not purposely selected. Therefore, we expect that the participating herds were typical of large Chinese dairy herds. However, no reliable data exist on the size and management of Chinese dairy herds for comparison.

Estimation of CICM was based on recording of CM by the farms. In our opinion, the estimate of CICM was more accurate when based on the relatively short pe- 
riod of 1 mo than a longer interval (e.g., the last year). Additionally, different from privately owned farms in most other countries, all of these large participating Chinese herds had dedicated personnel for data recording. Clinical mastitis cases were recorded on all farms. In an intensive Dutch study, $6 \%$ of farm CM data recording was not sufficient to be included in estimation of incidence rate of $\mathrm{CM}$, and in approximately $6 \%$ of CM no sample was collected (Barkema et al., 1999). Given the less intensive oversight in our study, CICM was likely underestimated.

In the near future, the antimicrobial susceptibility of these pathogens, phenotypically and genotyically, will be determined. Additionally, in future studies, more cow information (quarter location, and parity) and more herd-level information should be collected; however, in China very few herds are on DHI, so the quality of these data will mostly depend on individual herd recording systems.

\section{CONCLUSIONS}

In large dairy herds in China, the CICM was $3.3 \%$ per month. Escherichia coli, Klebsiella spp., CNS, Strep. dysgalactiae, Staph. aureus, and other streptococci were the most frequently isolated pathogens from bovine CM. Based on a high proportion of Staph. aureus, we inferred that routine monitoring for this contagious pathogen was essential and a prevention program should be developed and implemented for affected herds. The CICM was higher in summer, and distribution of CM pathogens was associated with season. In winter, streptococci were more prevalent, whereas coliforms were more frequently isolated in summer. The CICM was lower in herds using sand bedding. Streptococcus dysgalactiae was more frequently isolated in herds using sand bedding, whereas proportion of E. coli and Klebsiella spp. was higher in herds using organic bedding.

\section{ACKNOWLEDGMENTS}

This research was financially supported by the Chinese thirteen "Five-year" National Science and Technology Support Project (Beijing; No. 2016YFD0501203), Ministry of Education in China major project (Beijing; No. 313054), High-end Foreign Experts Recruitment Program (Beijing; No. GDT20171100013), and the National Natural Science Foundation of China (Beijing; No. 31572587 and No. 3151101034). The authors also thank staff of Animal Health Cattle, Boehringer Ingelheim International Trading (Shanghai) Co., as well as dairy managers and farm herdsmen and veterinarians for their participation.

\section{REFERENCES}

Barkema, H. W., Y. H. Schukken, T. J. Lam, M. L. Beiboer, G. Benedictus, and A. Brand. 1999. Management practices associated with the incidence rate of clinical mastitis. J. Dairy Sci. 82:1643-1654.

Barkema, H. W., Y. H. Schukken, T. J. Lam, M. L. Beiboer, H. Wilmink, G. Benedictus, and A. Brand. 1998. Incidence of clinical mastitis in dairy herds grouped in three categories by bulk milk somatic cell counts. J. Dairy Sci. 81:411-419.

Bi, Y., Y. J. Wang, Y. Qin, R. Guix Vallverdu, J. Maldonado Garcia, W. Sun, S. Li, and Z. Cao. 2016. Prevalence of bovine mastitis pathogens in bulk tank milk in China. PLoS One 11:e0155621.

Bradley, A. 2002. Bovine mastitis: An evolving disease. Vet. J. 164:116-128.

Bradley, A. J., K. A. Leach, J. E. Breen, L. E. Green, and M. J. Green. 2007. Survey of the incidence and aetiology of mastitis on dairy farms in England and Wales. Vet. Rec. 160:253-257.

Daniel, R. C., D. O'Boyle, M. S. Marek, and A. J. Frost. 1982. A survey of clinical mastitis in South-East Queensland dairy herds. Aust. Vet. J. 58:143-147.

Ericsson Unnerstad, H., A. Lindberg, K. Persson Waller, T. Ekman, K. Artursson, M. Nilsson-Ost, and B. Bengtsson. 2009. Microbial aetiology of acute clinical mastitis and agent-specific risk factors. Vet. Microbiol. 137:90-97.

Erskine, R. J., R. J. Eberhart, L. J. Hutchinson, S. B. Spencer, and M. A. Campbell. 1988. Incidence and types of clinical mastitis in dairy herds with high and low somatic cell counts. J. Am. Vet. Med. Assoc. 192:761-765.

Frank, J. A., C. I. Reich, S. Sharma, J. S. Weisbaum, B. A. Wilson, and G. J. Olsen. 2008. Critical evaluation of two primers commonly used for amplification of bacterial 16S rRNA genes. Appl. Environ. Microbiol. 74:2461-2470.

Gao, J., M. Ferreri, X. Q. Liu, L. B. Chen, J. L. Su, and B. Han. 2011. Development of multiplex polymerase chain reaction assay for rapid detection of Staphylococcus aureus and selected antibiotic resistance genes in bovine mastitic milk samples. J. Vet. Diagn. Invest. 23:894-901.

Gröhn, Y. T., R. N. Gonzalez, D. J. Wilson, J. A. Hertl, G. Bennett, H. Schulte, and Y. H. Schukken. 2005. Effect of pathogen-specific clinical mastitis on herd life in two New York State dairy herds. Prev. Vet. Med. 71:105-125.

Gröhn, Y. T., D. J. Wilson, R. N. Gonzalez, J. A. Hertl, H. Schulte, G. Bennett, and Y. H. Schukken. 2004. Effect of pathogen-specific clinical mastitis on milk yield in dairy cows. J. Dairy Sci. $87: 3358-3374$

Hogan, J. S., V. L. Bogacz, L. M. Thompson, S. Romig, P. S. Schoenberger, W. P. Weiss, and K. L. Smith. 1999. Bacterial counts associated with sawdust and recycled manure bedding treated with commercial conditioners. J. Dairy Sci. 82:1690-1695.

Hogan, J. S., K. L. Smith, K. H. Hoblet, D. A. Todhunter, P. S. Schoenberger, W. D. Hueston, D. E. Pritchard, G. L. Bowman, L. E. Heider, B. L. Brockett, and H. R. Conrad. 1989. Bacterial counts in bedding materials used on nine commercial dairies. J. Dairy Sci. 72:250-258.

Hogan, J. S., K. L. Smith, D. A. Todhunter, and P. S. Schoenberger. 1990. Bacterial counts associated with recycled newspaper bedding. J. Dairy Sci. 73:1756-1761.

Kristula, M. A., W. Rogers, J. S. Hogan, and M. Sabo. 2005. Comparison of bacteria populations in clean and recycled sand used for bedding in dairy facilities. J. Dairy Sci. 88:4317-4325.

Levison, L. J., E. K. Miller-Cushon, A. L. Tucker, R. Bergeron, K. E. Leslie, H. W. Barkema, and T. J. DeVries. 2016. Incidence rate of pathogen-specific clinical mastitis on conventional and organic Canadian dairy farms. J. Dairy Sci. 99:1341-1350.

Makovec, J. A., and P. L. Ruegg. 2003. Results of milk samples submitted for microbiological examination in Wisconsin from 1994 to 2001. J. Dairy Sci. 86:3466-3472.

McDougall, S. 1999. Prevalence of clinical mastitis in 38 Waikato dairy herds in early lactation. N. Z. Vet. J. 47:143-149. 
Morse, D., M. A. DeLorenzo, C. J. Wilcox, R. J. Collier, R. P. Natzke, and D. R. Bray. 1988. Climatic effects on occurrence of clinical mastitis. J. Dairy Sci. 71:848-853.

National Mastitis Council. 1999. Laboratory Handbook on Bovine Mastitis. NMC Inc., Madison, WI.

Olde Riekerink, R. G. M., H. W. Barkema, D. F. Kelton, and D. T Scholl. 2008. Incidence rate of clinical mastitis on Canadian dairy farms. J. Dairy Sci. 91:1366-1377.

Olde Riekerink, R. G. M., H. W. Barkema, and H. Stryhn. 2007. The effect of season on somatic cell count and the incidence of clinical mastitis. J. Dairy Sci. 90:1704-1715.

Oliveira, L., C. Hulland, and P. L. Ruegg. 2013. Characterization of clinical mastitis occurring in cows on 50 large dairy herds in Wisconsin. J. Dairy Sci. 96:7538-7549.

Osterås, O., L. Solverod, and O. Reksen. 2006. Milk culture results in a large Norwegian survey-effects of season, parity, days in milk, resistance, and clustering. J. Dairy Sci. 89:1010-1023.

Pinzón-Sánchez, C., V. E. Cabrera, and P. L. Ruegg. 2011. Decision tree analysis of treatment strategies for mild and moderate cases of clinical mastitis occurring in early lactation. J. Dairy Sci. 94:1873-1892.

Podder, M. P., L. Rogers, P. K. Daley, G. P. Keefe, H. G. Whitney, and K. Tahlan. 2014. Klebsiella species associated with bovine mastitis in Newfoundland. PLoS One 9:e106518.

Qi, J., A. Guo, P. Cui, Y. Chen, R. Mustafa, X. Ba, C. Hu, Z. Bai, X. Chen, and L. Shi. 2012. Comparative geno-plasticity analysis of Mycoplasma bovis HB0801 (Chinese isolate). PLoS One 7:e38239.

Reksen, O., L. Solverod, A. J. Branscum, and O. Osteras. 2006. Relationships between milk culture results and treatment for clinical mastitis or culling in Norwegian dairy cattle. J. Dairy Sci. 89:2928-2937.

Roberson, J. R., L. D. Warnick, and G. Moore. 2004. Mild to moderate clinical mastitis: efficacy of intramammary amoxicillin, frequent milk-out, a combined intramammary amoxicillin, and frequent milk-out treatment versus no treatment. J. Dairy Sci. 87:583-592.
Rowbotham, R. F., and P. L. Ruegg. 2016. Associations of selected bedding types with incidence rates of subclinical and clinical mastitis in primiparous Holstein dairy cows. J. Dairy Sci. 99:47074717.

Schukken, Y. H., F. J. Grommers, J. A. Smit, D. Vandegeer, and A. Brand. 1989b. Effect of freezing on bacteriologic culturing of mastitis milk samples. J. Dairy Sci. 72:1900-1906.

Schukken, Y. H., F. J. Grommers, D. van de Geer, and A. Brand. 1989a. Incidence of clinical mastitis on farms with low somatic cell counts in bulk milk. Vet. Rec. 125:60-63.

Smith, K. L., D. A. Todhunter, and P. S. Schoenberger. 1985. Environmental mastitis: Cause, prevalence, prevention. J. Dairy Sci. 68:1531-1553.

Stowell, R. R., and S. Inglis. 2000. Sand for bedding. Pages 226-234 in Dairy Housing and Equipment Systems: Managing and Planning for Profitability. Vol. 129. Natural Resource, Agriculture, and Engineering Service (NRAES), Ithaca, NY.

Todhunter, D. A., K. L. Smith, J. S. Hogan, and P. S. Schoenberger 1991. Gram-negative bacterial infections of the mammary gland in cows. Am. J. Vet. Res. 52:184-188.

Verbeke, J., S. Piepers, K. Supre, and S. De Vliegher. 2014. Pathogenspecific incidence rate of clinical mastitis in Flemish dairy herds, severity, and association with herd hygiene. J. Dairy Sci. 97:69266934 .

Wilesmith, J. W., P. G. Francis, and C. D. Wilson. 1986. Incidence of clinical mastitis in a cohort of British dairy herds. Vet. Rec. 118:199-204.

Zdanowicz, M., J. A. Shelford, C. B. Tucker, D. M. Weary, and M. A. von Keyserlingk. 2004. Bacterial populations on teat ends of dairy cows housed in free stalls and bedded with either sand or sawdust. J. Dairy Sci. 87:1694-1701.

Zhang, Z., X. P. Li, F. Yang, J. Y. Luo, X. R. Wang, L. H. Liu, and H. S. Li. 2016. Influences of season, parity, lactation, udder area, milk yield, and clinical symptoms on intramammary infection in dairy cows. J. Dairy Sci. 99:6484-6493. 